\title{
PROBLEM-BASED INTRODUCTION (PBI) LEARNING MODEL ON THE PROBLEM SOLVING ABILITY OF PROSPECTIVE ECONOMY TEACHERS
}

\author{
1Jusep Saputra, ${ }^{2}$ Chandra Aditya \\ ${ }^{1}$ Universitas Pasundan \\ Email: jusepsaputrapmat@unpas.ac.id
}

\begin{abstract}
Ability Problem solving of learners is needed in understanding the economy in order to support student learning achievement. But the problem-solving ability of learners was still low. This is because teachers rarely train the problem-solving skills of learners during the learning process. The purpose of this research is to analyze the implementation of PBI (Problem Based Introduction) model and how much influence of PBI (Problem Based Introduction) model to problem-solving ability. The research method is True Experimental Design (real experiment) The population in this research are all students SMA Negeri 27 Bandung. As for the sample of the research is the students of class X SMA Negeri 27 Bandung as much as two classes are randomly selected by class Instruments used in the research in the form of Multiple Choice type test questions problem-solving problem learners and a questionnaire scale using a Likert Scale model The data analysis is done using t-test, based on postes obtained data of independent samples test with sig value (2tailed) 0.12 Based on the result of the calculation, the writer concludes that the problemsolving ability of learners who get the model learning problem-based Introduction (PBI) is better than the problem-solving ability of learners who get expository exposure. Therefore, Problem Based Introduction (PBI) model can be used as an alternative for teachers in implementing their learning to create an active, effective and enjoyable learning atmosphere.
\end{abstract}

Keywords: Problem-Based Introduction (PBI); problem-solving skill.

\section{INTRODUCTION}

Education is one of the most important factors for the progress of the nation. Success or failure of education conducted will determine the advancement of a nation. Education is a major factor in the formation of the human person. Education is instrumental in shaping the good or bad of human person according to normative measure. With a good education system is expected to emerge the next generation of quality and able to adapt to live a society, nation, and state. The Director-General of Teachers and Education Personnel (GTK) reported that based on the results of Teacher Competency Test (UKG) administered at the end of 2015, the average scores was 53.02. The competencies tested are professional competence and pedagogic competency. Based on the data, it is still necessary to improve the quality of teachers in Indonesia, Darta \& Saputra (2018, p 2).

Along with the rapid flow of reform in the education sector, various efforts to improve the education system and its tools in Indonesia continue to be done, consequently emerging some educational regulations to complement each other and the improvement of regulations that are no longer relevant to the current needs. This can be seen with the enactment of Law RI No. 20 of 2003 on National Education System (Sisdiknas). As stated in the Law of National Education System no. 20 The Year 2003 in Chapter I Article 1 paragraph 1 that is, Education is a conscious and planned effort to create an atmosphere of learning and learning process so that learners actively develop their potential to have 
spiritual power of religion, self-control, personality, intelligence, noble character, and also skills needed himself, society, nation, and country.

Furthermore, Article 4 of the Law on National Education System no. 20 The Year 2003 states that Education is organized by developing a culture of reading, writing, and counting for all citizens. Therefore, to achieve the quality of good education required the implementation of good learning as well. From this understanding, the writer believes that the implementation of teaching and learning process is a core of education activities in schools. As the core of educational activities, teaching and learning process is an effort to achieve optimal learning objectives. The purpose of learning is shown by the changes in the students that lead to a positive or often called the achievement.

Economic education is part of education and as one of the most important lessons in school because the economy is a science that studies how human beings suffice their life. To achieve the target In addition to supporting the educational process, the educational economy also serves the education needs to prepare materials or learning environment that contains the economy. This material does not have to be a separate field of study but can be tucked into other lessons.

Recognizing the importance of a more fundamental understanding of the economic aspects leads to the importance of economic education to be provided to secondary school students with the aim that students are able to understand economics or termed proficient economic discourse (economic literacy). A proficient review of economic discourse not only from students' cognitive abilities is reflected in the level of school achievement alone, but also taken into account from the level of economic education in the family environment.

Learning in schools has many critics addressed to teachers about the way teachers give less emphasis on mastery of some information or concepts. We can not deny that concept is a very important thing, but it does not lie in the concept itself but lies in how the concept is understood by learners. The importance of conceptual understanding in teaching and learning processes greatly influences attitudes, decisions, ways of solving problems, and problem-solving skills of learning. The independence of study participants can be done if in the learning process provides an open opportunity for students to learn independently, Saputra (2017b, p. 117). in addition, self-efficacy is an important component developed, Saputra, Darta, and Eliyarti (2017c, p.117). All of these allow the ability to solve problems can be better than ever.

According to Saputra (2015a, p.78), "Efficient or problem-driven learning is driven by the innate desire of learners to personally investigate the situation". The fact in the field learners do not investigate and only memorize the concept and are less able to use the concept if it encounters real-life problems related to the concept. Furthermore, even learners are less able to determine the problem and formulate it. This will certainly affect the ability of learners in facing problems or a problem both in school and outside of school. According to Arends (Trianto, 2011, p. 90) in teaching teachers are always demanding learners to learn and rarely provide lessons on how learners to learn, teachers also demand learners to solve problems, but rarely teach how learners should solve problems.

The problem now is how to find the best way to convey the various concepts taught so students can use and remember longer the concept. How teachers can communicate well with learners. How teachers can open diverse thinking insights from all students, so as to learn the concepts and how to link them in real life. How as a good and wise teacher is able to use the learning model related to problem-solving (Problem Solving). Problem Based Introduction (PBI) model is a learning model based on many problems that require authentic investigation ie investigations that require real settlement of real problems. The fun learning process can be used as an entertainment, and no longer be a scary thing for students. So the interesting packaging of the student would surely get serious attention from the students, Saputra (2013, p 219).

The purpose of this study is to apply the PBI model and to measure the influence of PBI learning model on the problem-solving ability of learners on economic subjects. To bring learning goals in the direction that can improve problem-solving skills, learning should be 
more emphasis on authentic problem solving such as problems that occur in everyday life, Saputra (2015b, p.501).

In practice, teachers should remember that no learning model is most appropriate for all situations and conditions. Therefore, in choosing the right model of learning should consider the condition of learners, the nature of teaching materials, media facilities are available and the condition of the teacher itself. A learning model is basically a form of learning illustrated from beginning to end that is typically presented by the teacher. The use of learning model is very influential on learning outcomes of learners. One that is used in the learning process of learners is a PBI learning model or problem-based learning, including in economic subjects in high school.

Problem-based instruction can be an effective approach for teaching high-level thinking processes. This learning helps learners to process the ready-made information in their minds and develop their own knowledge. Learners should assume, collect information, interpret data, infer, analyze, and evaluate. Holil (2007) argues that this learning is suitable for developing both basic and complex knowledge. Problem-based instruction is developed to help learners develop thinking skills and problem-solving, thinking skills and involvement of learners in real experience. This model can be used to train and improve problem-solving skills as well as to gain knowledge of important concepts.

\section{THEORETICAL BASIS}

Problem Based Introduction (PBI) is a learning process that involves stimulus work and response to an existing problem in our environment to be analyzed, investigated, assessed, and solved. The process of learning based on the problem is also a learning with a higher level than conventional normal learning because students are required to think critically and creatively to the existing problems.

The syntax of a lesson contains practical steps that teachers and students must take in an activity. The problem-based teaching consists of 5 (five) major steps that begin with the teacher introducing students to the problem situation and ending with the presentation and analysis of student work. These five steps are described based on the steps in Table 1 .

Table 1. Problem-Based Syntax

\begin{tabular}{|c|c|}
\hline Step & Teacher behavior \\
\hline $\begin{array}{c}\text { Phase- } 1 \\
\text { The orientation of learners to } \\
\text { the problem }\end{array}$ & $\begin{array}{l}\text { The teacher explains the purpose of } \\
\text { learning, Explains the required logistics, } \\
\text { proposes phenomena or demonstrations } \\
\text { or stories to raise the problem, motivates } \\
\text { the learner to engage in the problem } \\
\text { solving he or she chooses. }\end{array}$ \\
\hline $\begin{array}{c}\text { Phase-2 } \\
\text { Organize learners to learn }\end{array}$ & $\begin{array}{l}\text { Teachers help learners to define and } \\
\text { organize learning tasks related to the } \\
\text { problem. }\end{array}$ \\
\hline $\begin{array}{c}\text { Phase-3 } \\
\text { Guiding individual and group } \\
\text { investigations }\end{array}$ & $\begin{array}{l}\text { Teachers encourage learners to gather } \\
\text { appropriate information, carry out } \\
\text { experiments, to gain explanations and } \\
\text { solve problems. }\end{array}$ \\
\hline $\begin{array}{c}\text { Stage-4 } \\
\text { Develop and present the work }\end{array}$ & $\begin{array}{l}\text { Teachers assist learners in planning and } \\
\text { preparing appropriate works such as } \\
\text { reports, videos, and models and helping } \\
\text { them to share tasks with their friends. }\end{array}$ \\
\hline
\end{tabular}




\begin{tabular}{cl}
\hline Step & \multicolumn{1}{c}{ Teacher behavior } \\
\hline Stage-5 & $\begin{array}{l}\text { Teachers help learners to reflect on or } \\
\text { evaluate their investigations and the } \\
\text { processes they use. }\end{array}$ \\
$\begin{array}{c}\text { Analyze and evaluate the } \\
\text { problem-solving process }\end{array}$ &
\end{tabular}

Cording Polya (Sopyan, 2008) that the process that can be done at each step on how to solve the problem is as follows:

Understand the problem. Student competencies in this step are: Determine: what is unknown? What is the data? What is the condition? May be expressed in terms of equations or others? Is the condition sufficient or excessive, or contradictory? Create a diagram, write a matching notation. Separate the different parts of the condition. Are you including people? Create a split plan. The student's competence in this step is Determine: have you seen this amount before? Is there a similar or similar problem in another form? Do you know the relationship of this problem? Which theory can be used in fashion? Cleanliness asked! Try the concept of a problem that has been encountered with the same or similar questions! If the problems are similar and that have been done before, can the universal experience be universal? Do you use the method? Can you find others to use the problem first? Do you conclude in another form? Revert to resolution. If the new thing cannot be resolved, guess what the problem is like and finish it.

Toll plan. The steps taken are the Implement plan of the solution, check every step. Are all the steps correct? Did you prove the step is correct?

Looking back at the results. Student Components in this step How to check the results already obtained? Checking the rebuttal? Looking for results in different ways? Change your breath? How to access or any other way to another problem?

If one of the three things is not met, then a problem is not a problem. If the rules or algorithms in solving a problem already exist in memory, then the problem cannot be said as a problem. Based on the above, problem-solving can be viewed as a form of learning that requires new things, which can be seen at the end of the learning activity.

According to NCTM (Yaniawati, 2010, p.114) the indicators of students problem solving abilities are: (1) learners can use with increased confidence, approach problems to investigate and understand content, (2) learners can apply the merging of breaking strategies (3) learners can introduce and formulate solutions from situations inside and outside content contents, and (4) learners apply processes from models to real-world problem situations.

\section{METHODS}

The method used in this study is the True Experimental Design method (a true experiment) used because, in this design, the researcher can control all external variables that influence the course of the experiment. The form of research True Experimental Design used in this study is Pretest-Posttest Control Group Design because in this design there is one group selected at randomly.

The Population is a generalization region consisting of objects or subjects that have certain qualities and characteristics set by researchers to be studied and then drawn conclusions (Sugiyono, 2010: 117). As for the population in this study are all students class X, XI, and XII amounting to 629 people in SMA Negeri 27 Bandung 2011-2012 academic year as a subject in this study. The author selects one class at random to sample. Thus, obtained class X-4 amounted to 39 students as an experimental class that get PBI learning model.

The data collection techniques conducted in this study are literature study, interview (interview), questionnaire (questionnaire), observation, test. Hypothesis testing through the one-party test using independent sample t-test, with the help of SPSS software. 


\section{RESULTS AND DISCUSSION}

The class is normally distributed, then tested Hypothesis with t-test through SPSS program using Independent Sample T-Test with significance level 0,05. After data processing, the final test result t-test (postest) can be seen in Table 2.

\begin{tabular}{rrrrrrrrr}
\multicolumn{10}{c}{ Table 2. Test-t Final Test (Postes) } \\
Independent Samples Test \\
\hline F & Sig. & t & df & $\begin{array}{c}\text { Sig. (2- } \\
\text { tailed) }\end{array}$ & $\begin{array}{c}\text { Mean } \\
\text { Difference }\end{array}$ & $\begin{array}{c}\text { Std. Error } \\
\text { Difference }\end{array}$ & Lower & Upper \\
\hline 2.635 & .109 & 8.475 & 76 & .024 & 15.846 & 1.870 & 12.122 & 19.570
\end{tabular}

In Table 2 -value $=0,024$ / $2=0.012<\alpha=0.05$ then $\mathrm{H} 0: \mu 1=\mu 2$ is rejected and $\mathrm{Ha}: \mu 1>\mu 2$ is accepted, so it can be concluded that there is difference of problem solving ability of learners who get PBI learning model with learners receiving expository learning.

The scale of attitudes that are held contains questions of learners of the PBI learning model. The average student attitudes toward the PBI Learning Model is 3.84. Because $3.84>3.00$ it can be concluded that the attitudes of learners positively to the PBI Learning Model. The average student attitudes toward problem-solving are 3.62. Because 3.62> 3.0 then it can be concluded that the attitude of students positive to problem-solving.

Based on the above calculation, the experimental class is normally distributed, so the t-test is done through SPSS program using One =-Sample T-Test with a significance level of 0.05 , and tested by one side is the right side test. After data processing, the final test result t-test can be seen in Table 3.

Table 3. Test-t Scale Attitude Class Experiment

\begin{tabular}{|c|c|c|c|c|c|c|}
\hline \multicolumn{7}{|c|}{ One-Sample Test } \\
\hline \multicolumn{7}{|c|}{ Test Value $=3$} \\
\hline & \multirow[b]{2}{*}{$\mathrm{T}$} & \multirow[b]{2}{*}{ Df } & \multirow[b]{2}{*}{ Sig. (2-tailed) } & \multirow{2}{*}{$\begin{array}{c}\text { Mean } \\
\text { Difference }\end{array}$} & \multicolumn{2}{|c|}{$\begin{array}{l}\text { 95\% Confidence } \\
\text { Interval of the } \\
\text { Difference }\end{array}$} \\
\hline & & & & & Lower & Upper \\
\hline Rerata & 13.655 & 29 & .034 & .73267 & .6229 & .8424 \\
\hline
\end{tabular}

In Table 3 the $p$-valued value $0.034 / 2=0.017<\alpha=0.05$, then $\mathrm{HO}: \mu 0=3.00$ is rejected and $\mathrm{Ha}: \mu 0>3.00$ is accepted, so it can be concluded that the students are positive towards the use of the PBI Learning Model in Economic learning is more than 3 . This means that the student population is positive towards the use of the PBI Learning Model.

To find out the initial problem-solving tricks students have learned from the environment and the learning experience, a pretesting is done. Based on pretest test results, there were no significant differences in the experimental and control classes. This situation is very helpful to see the development of students' problem-solving trajectory after the learning takes place.

Based on the results of the study, there are differences in the economic problemsolving tray of learners who get PBI learning model with expository learning. The economic problem-solving tray of learners who get the PBI learning model has an influence of $12 \%$. This is in line with what Trianto (2011: 96) says, "Problem-based teaching has advantages: (1) Realistic in student life, (2) Concept according to student needs; (3) fostering the nature of student inquiry; (4) strong concept retention; and (5) cultivate Problem Solving skills. "

For students who get a PBI learning model can more quickly understand the concept of economics and able to develop problem-solving skills, because in the learning process students do the problems in groups and make presentations directly, discuss and listen to information about the material gain a deeper understanding of the material at the time of 
view presentation, and can find and find the answer to a question in question. This situation allows students to have a better experience in finding a solution to economic problems.

Based on the results of attitude scale data analysis, it appears that learners positively to the use of $\mathrm{PBI}$ learning model in Economic learning and have a great influence on the problem-solving skills of learners. Application of PBI learning model can also reduce student's displeasure to Economics, learners can learn well, and complete the task correctly. In harmony with that, Ruseffendi (2006, p. 234) states, "A student's positive attitude is to take the lessons seriously, be able to complete the assigned task well, thoroughly and on time, actively participate, and can respond well challenges given ".

Based on the findings of field researchers, with the PBI learning model, students become more serious in their learning, especially when working on the questions, and they are not afraid or embarrassed to ask the teacher, and when the teacher asks who wants to do the questions most students want to participate. However, not all learners change the way of learning, but in general, students become more active when learning Economics.

The findings obtained from the scale of attitudes for the average maximum statement are in the positive statements of number 3 obtained by the average of 4.15 ie "By studying group discussions I find it helpful in studying the material", which means that many students who agree to the statement, because when this learning applied, the attitude of learners to be not lazy or diligent even will accelerate learning as in working on LKS, and do homework. This is in accordance with the basic concept of PBI learning model, which is the advantages of the learning. Furthermore, the attitude scale for the average minimum statements contained in negative statements number 1 obtained 3.03 mean "I think the economic lesson is very difficult", which means that many students who disagree with the statement, but many also agreed and neutral so that the average value is close to neutral. This is because there are still many students who find it difficult in solving economic problems, it happens because students are not accustomed to thinking fast to solve problems directly.

From the results of this study as has been stated in the previous section, gives an idea that the PBI learning model can provide better contribution and greatly affect the ability of solving learning problems on the economic subjects of learners, so it can serve as a vehicle for developing the ability to solve economic problems and able to apply it in everyday life. In the end, students are expected to become more familiar with the subject matter learned, so that a positive impact on learning outcomes and problem-solving skills.

The advantages of the PBI learning model is that learners can enjoy the learning process in a conducive atmosphere and with the relaxed learning process, fun and free from pressure, both physical and psychic, learners can construct their own knowledge, express their opinions freely without fear of blame, opportunity to discuss and cooperate with classmates.

Basically, there are many advantages of PBI learning model. In practice, however, it is not easy to integrate all learning styles into elements in the PBI learning model. This is seen when at first many learners who have difficulty to follow the learning process, but for the next most learners begin to follow the learning process well.

In addition, other things that become obstacles in this research when learners have to present the results of the work of the group starts from reading the resume to answer questions raised by other groups about the material National Income being discussed that takes a lot of time. Based on the learner's statement, the presentation process of a particular problem situation is a waste of time. When given the problem that requires the learner to think to solve the problem concerning the material being discussed that is the material of National Income, the student must first read the group task, then open the question session aimed at the other group to ask until then the question is answered by the presenter group in front of the class. This discussion process takes a long time. Therefore, to overcome these obstacles, the researchers limit the time spent on each group to present their group results in front of the 25-minute class of each group. The use of time 25 minutes is 10 minutes to read out the resume of the discussion and 15 minutes to answer questions. In 
addition, the researchers also limit the question posed by other groups to the group of presenter only 3 questions, so that it can utilize and make the time as possible.

\section{CONCLUSIONS}

Based on the results of data analysis and hypothesis testing, the writer can draw the conclusion that are: (1) The implementation of Problem Based Introduction (PBI) model applies the steps that consist of student orientation to problem, organize learners to learn, guide individual investigation group, develop and present the work, and analyze and evaluate the problem-solving process; (2) The ability of economic problem-solving learners who get the Problem Based Introduction (PBI) learning model is better than expository learning; (3) Problem Based Introduction (PBI) learning model has $12 \%$ influence on students problem-solving ability on economic subjects. In his research, the researchers will add additional media by trying to maple the program. Self-regulated learning of high-ranked and low-ranked students who are a student of Saputra (2017a).

\section{BIBLIOGRAPHY}

Darta \& Saputra, J. (2018). Indicators that Influence Prospective Mathematics Teachers Representational and Reasoning Abilities. Journal of Physics: Conference Series 948 (1), 012053. DOI :10.1088/1742-6596/948/1/012053.

Holil, A. (2007). Model pembelajaran Kooperatif. Tersedia: www.anwarholil.blogspot.com/2007/09/pembelajarankooperatif

Ruseffendi, E. T. (2006). Pengantar kepada Membantu Guru Mengembangkan Kompetensinya dalam Pengajaran Matematika untuk Meningkatkan CBSA. Bandung: Tarsito.

Saputra, J. (2013). Pengaruh Model Pembelajaran Edutainment dengan Pendekatan Somatic, Auditory, Visualization, And Intelectually (SAVI) terhadap Kemampuan Komunikasi Matematis Siswa SMA. SYMMETRY: Jurnal Pendidikan Matematika, 4 (1), 217-226.

Saputra, J. (2015a). Penggunaan Model Problem Based Learning Berbantuan E-Learning Dalam Upaya Meningkatkan Kemampuan Pemecahan Masalah Matematis dan Dampaknya terhadap Kemandirian Belajar Mahasiswa. Pasundan Journal of Mathematics Eduation Jurnal Pendidikan Matematika, 5 (2), 77-87.

Saputra, J. (2015b). Program Maple untuk Meningkatkan Kemampuan Komunikasi Matematis Mahasiswa Calon Guru. SYMMETRY: Jurnal Pendidikan Matematika, 4 (2), 597-605.

Saputra, J. (2017a). The application of the Maple Program to Self-Regulated Learning on The Mathematics' Prospective Teachers Students. International Conference: Character Building Through Pricesly International Education Series 1 (1).

Saputra, J. (2017b). Penggunaan Model Problem Based Learning Berbantuan E-Learning Terhadap Kemandirian Belajar Mahasiswa pada Dimensi Tiga. KALAMATIKA Jurnal $\begin{array}{llll}\text { Pendidikan Matematika, } & 2 & \text { (2), }\end{array}$ DOI: http://dx.doi.org/10.22236/KALAMATIKA.vol2no2.2017pp117-130

Saputra, J., Darta \& Eliyarti, W. (2017c). Kemampuan Self-efficacy pada Mahasiswa Tingkat Pertama Calon Guru Matematika. Prosiding Seminar Nasional Matematika dan Pendidikan Matematika, 5 (5), 117. Tersedia di http://publikasi.stkipsiliwangi.ac.id/prosiding/prosiding-seminar-nasional-matematikadan-pendidikan-matematika-tahun-2017/

Setiani, A. (2014). Pembelajaran Matematika dengan Pendekatan Problem Based Learning (Pbl) untuk Mengurangi Kecemasan Matematika dan Meningkatkan Kemampuan Pemecahan Masalah Matematis Siswa Mts. Tesis di Pascasarjana UNPAS, Bandung: Tidak diterbitkan. 
Sopyan, D. (2008). Pembelajaran Berbasis Masalah untuk Meningkatkan Kemampuan Pemecahan Masalah dan Kemampuan Komunikasi Siswa Sekolah Menengah Pertama. Tesis pada PPS UPI, Bandung: Tidak diterbitkan.

Sugiyono. (2010). Metode Penelitian Pendidikan. Bandung: CV Alfabeta.

Sugiyono. (2010). Statistika Untuk Penelitian. Bandung: CV Alfabeta.

Trianto. (2011). Mendesain Model Pembelajaran Innovatif-Progresif. Surabaya: Kencana (Prenada Media Group).

Uyanto. S. S. (2006). Pedoman Analisis Data dengan SPSS. Yogyakarta: Graha IImu. Yaniawati, P. (2010). E-learning: Alternatif Pembelajaran Kontemporer. Bandung: Arfino Raya. 